\title{
Morphometric Measurement and Types of Articular Facets on the Talus and Calcaneus in an Anatolıan Population
}

\author{
Mediciones Morfométricas y Tipos de Facetas Articulares \\ en el Talus y Calcáneo de una Población Anatolia
}

\author{
Neslıhan Boyan*; Esın Ozsahın**; Emıne Kızlkanat*; Roger Soames**** \& Ozkan Oguz*
}

BOYAN, N.; OZSAHIN, E.; KIZILKANAT, E.; SOAMES, R. \& OGUZ, O. Morphometric measurement and types of articular facets on the talus and calcaneus in an Anatolian population. Int. J. Morphol., 34(4):1378-1385, 2016.

SUMMARY: Anatomical variations in terms of ligamentous attachments, articulations and bony morphology are common in the subtalar region. The shape of the articular facets of the talus and calcaneus and their relationship to each other are important for joint function and surgical procedures. In this study an assessment of the morphology of the articular facets of the talus and calcaneus, in an Anatolian population, was undertaken. 49 tali and 57 calcanei from Anatolian adults of unknown gender were examined. The types of articular facets on the talus and calcaneus were determined using the following classification: Type A1, the distance between the anterior and middle facets was less than $2 \mathrm{~mm}$; Type A2, the distance between the anterior and middle facets was 2-5 mm; Type A3, the distance between the anterior and middle facets was more than $5 \mathrm{~mm}$; Type A4, there was only one articular facet; Type B1, the separation between the anterior and middle facets was not complete; Type B2, separation of the anterior and middle facets was present; Type C, no separation between the anterior, middle and posterior facets was present, i.e. there was one articular facet. In addition, the anteroposterior length and width of the talus and calcaneus, together with the width, length and depth of sulcus tali and sulcus calcanei were determined. Left and right tali, respectively, displayed the folowing types of articular facet: A1, $0 \%, 0 \% ; \mathrm{A} 2,0 \%, 3,4 \% ; \mathrm{A} 3,0 \%, 0 \% ; \mathrm{A} 4,0 \%, 0$ $\%$; B1, $60 \%, 51,8 \%$; and B2, $40 \%, 44.8 \%$. Articular facets on left and right calcanei, respectively, were: A1, $10 \%, 7.4 \%$; A2, $10 \%$, $14.8 \%$; A3, $16.7 \%, 11.1 \%$; A4, $3.3 \%, 3.7 \%$; B1, $30 \%, 22.2 \%$; B2, $30 \%, 40.8 \%$. The length and width of left and right tali were $50.5 \pm 3.81 \mathrm{~mm}$ and $39.5 \pm 2.97 \mathrm{~mm}$, and $53.1 \pm 4.38 \mathrm{~mm}$ and $39.3 \pm 3.66 \mathrm{~mm}$, respectively. The width, length and depth of left and right sulcus tali were: $5.2 \pm 1.09 \mathrm{~mm}, 21.7 \pm 2.73 \mathrm{~mm}$ and $5.7 \pm 0.84 \mathrm{~mm}$, and $6.1 \pm 2.05 \mathrm{~mm}, 21.1 \pm 3.66 \mathrm{~mm}$ and $5.7 \pm 1.52 \mathrm{~mm}$, respectively. For left and right calcanei length and width were; $76.1 \pm 5.44 \mathrm{~mm} 44.0 \pm 3.97 \mathrm{~mm}$, and $75.7 \pm 6.76 \mathrm{~mm}$ and $45.9 \pm 4.21 \mathrm{~mm}$, respectively. The width, length and depth of left and right sulcus calcanei were: $6.4 \pm 1.19 \mathrm{~mm}, 31.9 \pm 2.76 \mathrm{~mm}$ and $4.0 \pm 0.81 \mathrm{~mm}$, and $5.5 \pm 1.00 \mathrm{~mm}$, $32.4 \pm 3.23 \mathrm{~mm}$ and $4.4 \pm 1.05 \mathrm{~mm}$, respectively. The articular facets on both the talus and calcaneus in the Anatolian population studied was predominantly type B. This observations is similar to previous reports conducted in America, India and Africa, but differ from those undertaken in Europe. A knowledge of variations of the articular facets of the talus and calcaneus provides a valuable road map for orthopaedic surgeons, as well as others involved in foot rehabilitation.

KEY WORDS: Calcaneus; Facet; Talus; Subtalar.

\section{INTRODUCTION}

The morphology of the articular facets of the talus and calcaneus is of interest to anatomists (Anjaneyulu et al., 2014), but more importantly the relationship between them is critical in anthropometry, kinesiology, orthopaedic surgery, physical therapy and rehabilitation (Uygur et al., 2009). Differences with respect to race, as well as individual charactestics, suggest that the articular facets plays a key role in both static and dynamic kinetics of the foot and ankle.

The calcaneus, the largest of the tarsal bones, is irregularly cuboidal with its long axis inclined distally superolaterally: it is situated inferior and extends posterior to the talus and is the weight bearing tarsal bone (Williams \& Bannister, 1995; Uygur et al.; Sharada et al., 2012; Garg et al., 2013; Anjaneyulu et al.). Its anterior third is partly articular, while distal (anterior) to the posterior articular facet is a rough depression that narrows into a groove medially to form the sulcus calcanei. The elongated articular area distal and medial to the sulcus calcanei covers the sustentaculum tali and extends from the distal aspect of the body. This facet is often

\footnotetext{
* Cukurova University, Faculty of Medicine, Department of Anatomy, Adana, Turkey;

** Baskent University, Adana Research and Teaching Hospital, Department of Anatomy, Adana, Turkey;

*** Centre for Anatomy and Human Identification, School of Science and Engineering, University of Dundee, Dundee, UK.
} 
divided by a non-articular interval at the anterior border of the sustentaculum tali, to form the middle and anterior facets for the talus: these vary with sex and race (Gupta et al., 1977; Williams \& Bannister; Sharada et al.). Rarely, all three facets on the upper surface of the calcaneus fuse into a single irregular area (Williams \& Bannister). However, except for these rare cases three pairs of subtalar joint facets and the posterior facet are separated from the middle facets by the sulcus tali on the talus and the sulcus calcanei. The anterior and middle facets, which are part of the talocalcaneonavicular joint, are frequently continuous and show diverse anatomic variations (Linklater et al., 2009; Anjaneyulu et al.; Jung et al., 2015).

The talus is the bridge between the leg and the foot: it has no muscle attachments, but due to its involvement in the ankle, subtalar and talocalcaneonavicular joints has numerous ligamentous attachments (Williams \& Bannister; Bilodi, 2006; Öznur et al., 2013). On its plantar surface is the deep sulcus tali, which with the sulcus calcanei forms the sinus tarsi. The posterior talar facet articulates with the middle third of the calcaneus and is oval and convex anteroposteriorly.

The articulation between the talus and calcaneus is by posterior and anterior compartments separated by the sinus tarsi and canalis tarsi. The posterior compartment, often referred to as the subtalar joint, comprises the posterior facets of the calcaneus and talus, while the anterior compartment corresponds to the talocalcaneonavicular joint. Anteriorly, the concavity formed by the middle and anterior calcaneal facets support the head of the talus (Shahabpour et al., 2011). The subtalar joint is a prerequisite for human locomotion, with the most important motions of the subtalar complex being inversion (a complex movement combining plantarflexion, supination and adduction) and eversion (corresponding to dorsiflexion, pronation and abduction). The subtalar complex is a polyaxial articulation, consequently movement does not occur about a single fixed axis of rotation (Uygur et al.; Shahabpour et al.; Sharada et al.; Jung et al.). The articular facets of the sustentaculum tali have different configurations, but because they influence subtalar joint stability they are functionally important (Anjaneyulu et al.).

These anatomic features should be precisely evaluated and correlated with biomechanical and physiologic data to develop more effective treatments for disability involving the subtalar complex. Consequently, analysis of the articular surfaces of the subtalar joint provide vital information in understanding the dynamics of the foot, especially following as postoperative fixation and artificial joint production.
The calcaneus is the most frequently injured tarsal bone, with calcaneal fractures accounting for some $60 \%$ of all major tarsal injuries: most fractures are intra-articular with subtalar joint involvement. Talocalcaneal coalition may occur at any of the three facets, however the majority involve the middle facet: tarsal coalition is frequently a cause of painful flatfoot (Anjaneyulu et al.).

In various pathologies of the foot, such as talocalcaneal arthritis and coalition, intra-articular fractures, congenital dismorphology, flat foot, valgus deformities, the size and shape of the bones, the relationship between the talus and calcaneus and with other bones of the foot, must be borne in mind when performing both internal and external fixation and other surgical procedures (Uygur et al.; Sharada et al.; Anjaneyulu et al.). A detailed knowledge and understanding of the anatomic variations of the anterior and middle facets, the sustentaculum tali and the sinus tarsi is crucial in order to ensure that the osteotomy remains extraarticular (Anjaneyulu et al.).

The scope of the present study was to assess the type of joint facet on the talus and calcaneus, as well as the overall morphology of the talus and calcaneus in Anatolian population of Turkey. The observations of this study will be of use to orthopaedics surgeons undertaking various surgical procedures. Furthermore, a knowledge of anatomic variations is critical to determine the presence of talocalcaneal coalition, which may be fibrous (syndesmosis), cartilaginous (synchondrosis) or osseous (synostosis) (Linklater et al., 2009).

\section{MATERIAL AND METHOD}

Forty nine dry tali (20 left, 29 right) and 57 (30 left, 27 right) dry calcanei from an Anatolian adult popuation of unknown gender from those housed in the collection at the Department of Anatomy, Faculty of Medicine Cukurova University were examined. None of the specimens had any apparent signs of physical damage or pathological trauma.

The types of articular facets on the talus (Fig. 1A) and calcaneus (Fig. 2) were assessed using the following classification based on Bunning \& Barnett (1965), Forriol Campos \& Gomez Pellico (1989), Uygur et al., Mol et al. (2012), Sarvaiya et al. (2012) and Cho et al. (2014). In type A, anterior and middle articular facets were observed; however the extent of their seperation differed giving rise to four subtypes: A1, the distance between the articular facets was less than $2 \mathrm{~mm} ; \mathrm{A} 2$, the distance between the facets was $2-5 \mathrm{~mm}$; A3, the distance between the facets was more 

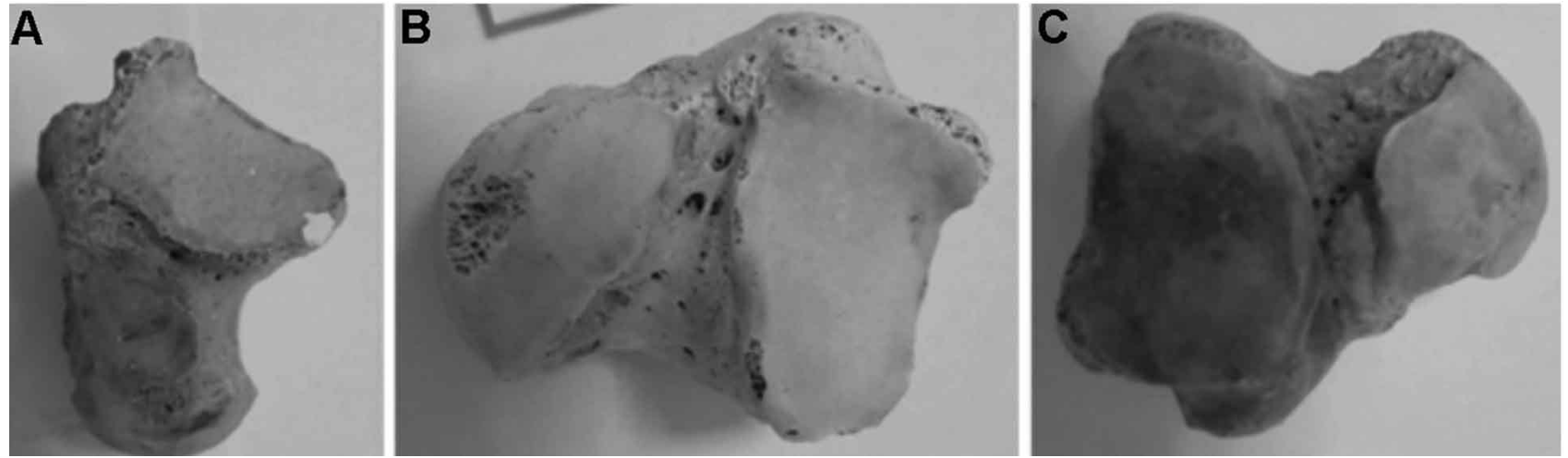

Fig. 1. Articular facet types of talus: A. Type A2; B. Type B1; C. Type B2.
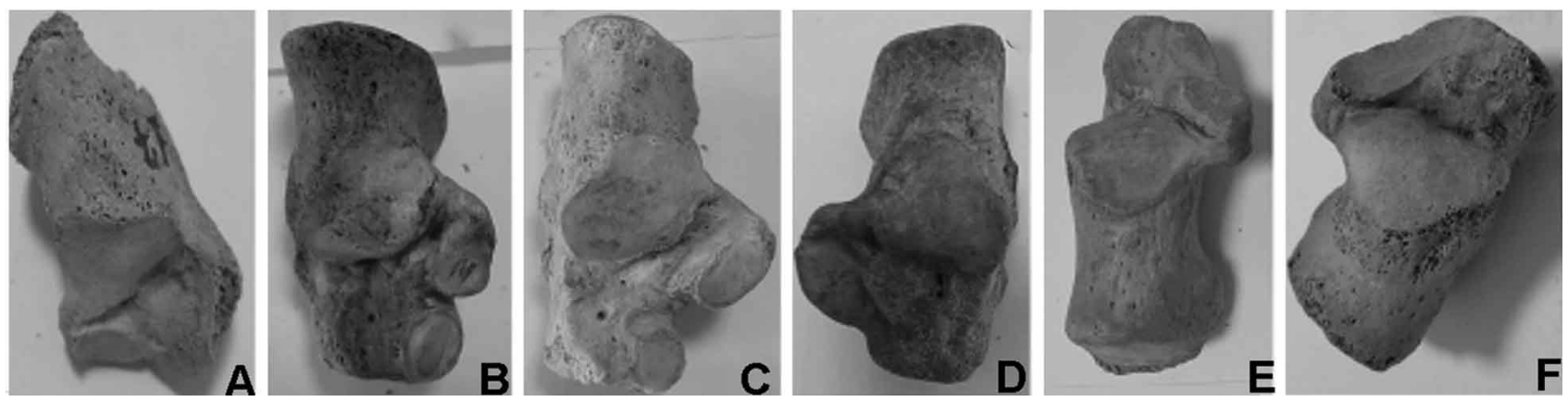

Fig. 2. Articular facet types of calcaneus: A. Type A1; B. Type A2; C. Type A3; D. Type A4; E. Type B1; F. Type B2.
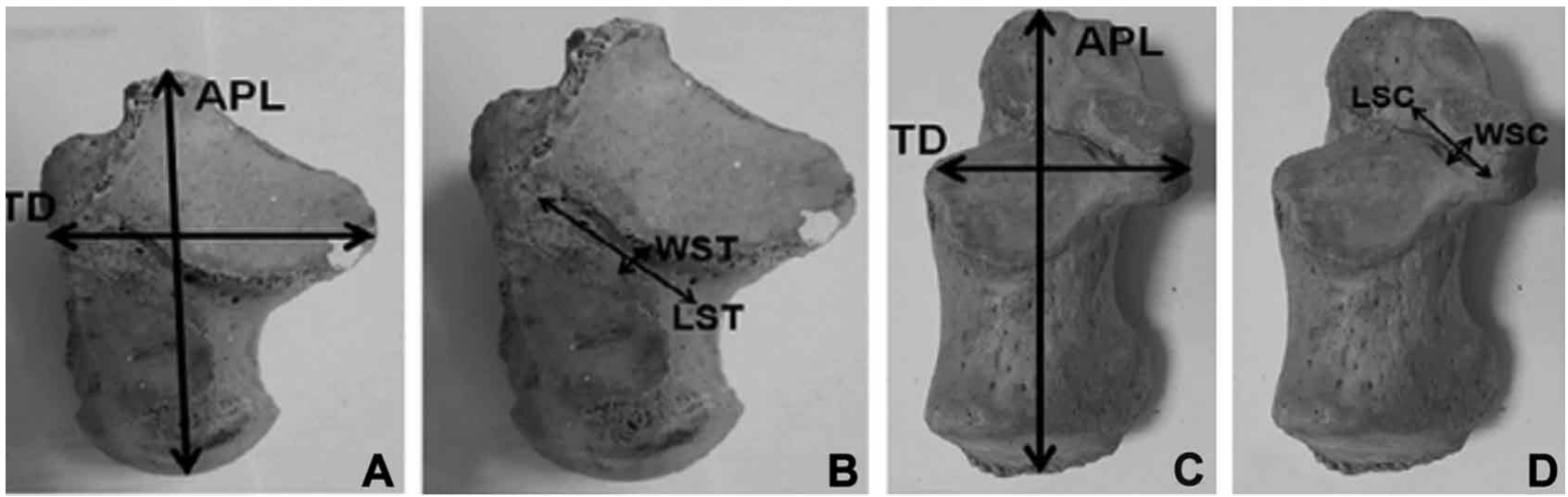

Fig. 3. Talus: A. APL: Anteroposterior length, TD: Transverse width; B. WST: width of the sulcus tali, LST: length of the sulcus tali. Calcaneus: C. APL: Anteroposterior length, TD: Transvers width; D. WSC: width of the sulcus calcanei, LSC: length of the sulcus calcanei.

than $5 \mathrm{~mm}$; and A4, only one articular facet was present. In type B there was no seperation between the anterior and middle articular facets, but was also divided into two subtypes: B1 in which the separation was incomplete, and B2 in which there was no separation between the facets. In type $\mathrm{C}$ there was no seperation between the anterior, middle and posterior articular facets: i.e. only a single articular facet was present.
In addition, the anteroposterior length and transverse width of the talus and calcaneus, together with the width, length and depth of the sulcus tali and sulcus calcanei were determined using a digital caliper accurate to $0.01 \mathrm{~mm}$ (Fig. 3 ). The lengths of talus and calcaneus were taken as the distance between the most anterior point on the anterior surface and most posterior point on the posterior surface; the transverse widths of the talus and calcaneus were taken 
as the distance between most medial point on the medial surface and most lateral point on the lateral surface; the width of the sulcus tali was taken as the distance between the anterior and posterior margins of the sulcus, while the width of the sulcus calcanei was taken as the distance between medial and lateral margins of the sulcus; the length of the sulcus tali was taken as the distance between medial and lateral margins of the sulcus, while the length of the sulcus calcanei was taken as the distance between anterior and posterior margins of the sulcus; finally the depth of the sulcus tali/ sulcus calcanei was taken as the distance between the margin and floor of the sulcus.

\section{RESULTS}

Using the classification outlined above the following types of articular facet were observed on the left and right tali: A1, $0 \%, 0 \%$; A2, $0 \%, 3.4 \%$; A3, $0 \%, 0 \%$; A4, $0 \%$, $0 \%$; B1, $60 \%, 51.8 \%$; B2, $40 \%, 44.8 \%$; and C, $0 \%, 0 \%$, respectively (Table I). While for the left and right calcanei the following types of facet were observed: A1; $10 \%, 7.4$ $\%$; A2, $10 \%, 14.8 \%$; A3, $16.7 \%, 11.1 \%$; A4, $3.3 \%, 3.7 \%$; B1, $30 \%, 22.2 \%$; B2, $30 \%, 40.8 \%$; and C, $0 \%, 0 \%$, respectively (Table I). The most common type of articular facet on both the talus and calcaneus in the Anatolian population studied was type $\mathrm{B}$.

The anteroposterior length and transverse width of left and right tali were: $50.51 \pm 3.81 \mathrm{~mm}$ and $39.50 \pm 2.97 \mathrm{~mm}$, and $53.05 \pm 4.38 \mathrm{~mm}$ and $39.33 \pm 3.66 \mathrm{~mm}$, respectively. The width, length and depth of the left and right sulcus tali were: $5.22 \pm 1.09 \mathrm{~mm}, 21.66 \pm 2.73 \mathrm{~mm}$ and $5.72 \pm 0.84 \mathrm{~mm}$, and $6.08 \pm 2.05 \mathrm{~mm}, 21.06 \pm 3.66 \mathrm{~mm}$ and $5.66 \pm 1.52 \mathrm{~mm}$, respectively (Table II). For the left and right calcanei the anteroposterior length and transverse width were: $76.07 \pm 5.44$ $\mathrm{mm}$ and $43.92 \pm 3.97 \mathrm{~mm}$, and $75.69 \pm 6.76 \mathrm{~mm}$ and $45.84 \pm 4.21 \mathrm{~mm}$, respectively. The width, length and depth of left and right sulcus calcanei were: $6.43 \pm 1.19 \mathrm{~mm}$, $31.85 \pm 2.76 \mathrm{~mm}$ and $3.99 \pm 0.81 \mathrm{~mm}$, and $5.53 \pm 1.00 \mathrm{~mm}$, $32.42 \pm 3.23 \mathrm{~mm}$ and $4.43 \pm 1.05 \mathrm{~mm}$, respectively (Table III).

Table I. Number and percentage of articular facet types observed on the talus and calcaneus.

\begin{tabular}{lllllllll}
\hline & \multicolumn{3}{l}{ Talus $(\mathbf{n}=\mathbf{4 9})$} & \multicolumn{5}{c}{ Calcaneus $(\mathbf{n}=\mathbf{5 7})$} \\
Parameters & $\begin{array}{l}\text { Left } \\
\text { P }\end{array}$ & \multicolumn{2}{l}{ Right } & \multicolumn{3}{c}{ Left } & \multicolumn{2}{c}{ Right } \\
& $\mathbf{n}$ & $\mathbf{( \% )}$ & $\mathbf{n}$ & $\mathbf{( \% )}$ & $\mathbf{n}$ & $\mathbf{( \% )}$ & $\mathbf{n}$ & $\mathbf{( \% )}$ \\
\hline Type A1 & 0 & 0 & 0 & 0 & 3 & 10 & 2 & 7.4 \\
Type A2 & 0 & 0 & 1 & 3.4 & 3 & 10 & 4 & 14.8 \\
Type A3 & 0 & 0 & 0 & 0 & 5 & 16.7 & 3 & 11.1 \\
Type A4 & 0 & 0 & 0 & 0 & 1 & 3.3 & 1 & 3.7 \\
Type B1 & 12 & 60 & 15 & 51.8 & 9 & 30 & 6 & 22.2 \\
Type B2 & 8 & 40 & 13 & 44.8 & 9 & 30 & 11 & 40.8 \\
Type C & 0 & 0 & 0 & 0 & 0 & 0 & 0 & 0 \\
Total & 20 & 100 & 29 & 100 & 30 & 100 & 27 & 100 \\
\hline
\end{tabular}

Table II. The means, standard deviations and range of the distances measured on left and right tali.

\begin{tabular}{lllll}
\hline Parameters & $\begin{array}{l}\text { Left } \\
\text { Range }\end{array}$ & Mean \pm SD & $\begin{array}{l}\text { Right } \\
\text { Range }\end{array}$ & Mean \pm SD \\
\hline Anteroposterior length $(\mathbf{m m})$ & $58.36-43.05$ & $50.51 \pm 3.81$ & $61.65-46.83$ & $53.05 \pm 4.38$ \\
Transverse width $(\mathbf{m m})$ & $44.56-33.70$ & $39.50 \pm 2.97$ & $45.56-27.85$ & $39.33 \pm 3.66$ \\
Sulcus tali width $(\mathbf{m m})$ & $7.09-3.41$ & $5.22 \pm 1.09$ & $14.70-3.45$ & $6.08 \pm 2.05$ \\
Sulcus tali length $(\mathbf{m m})$ & $26.97-15.85$ & $21.66 \pm 2.73$ & $30.98-16,35$ & $21.06 \pm 3.66$ \\
Sulcus tali depth $(\mathbf{m m})$ & $7.22-4.59$ & $5.72 \pm 0.84$ & $8.90-2.16$ & $5.66 \pm 1.52$ \\
\hline
\end{tabular}

Table III.The means, standard deviations and range of the distances measured on left and right calcanei.

\begin{tabular}{lllll}
\hline Parameters & $\begin{array}{l}\text { Left } \\
\text { Range }\end{array}$ & Mean \pm SD & $\begin{array}{l}\text { Right } \\
\text { Range }\end{array}$ & Mean \pm SD \\
\hline Anteroposterior length $(\mathbf{m m})$ & $84.83-64.94$ & $76.07 \pm 5.44$ & $86.35-62.17$ & $75.69 \pm 6.76$ \\
Transverse width $(\mathbf{m m})$ & $50.23-34.64$ & $43.92 \pm 3.97$ & $53.28-37.63$ & $45.84 \pm 4.21$ \\
Sulcus calcanei width $(\mathbf{m m})$ & $10.02-4.38$ & $6.43 \pm 1.19$ & $7.95-3.68$ & $5.53 \pm 1.00$ \\
Sulcus calcanei length $(\mathbf{m m})$ & $37.22-25.90$ & $31.85 \pm 2.76$ & $36.85-25.26$ & $32.42 \pm 3.23$ \\
Sulcus calcanei depth $(\mathbf{m m})$ & $5.87-2.33$ & $3.99 \pm 0.81$ & $7.52-2.80$ & $4.43 \pm 1.05$
\end{tabular}




\section{DISCUSSION}

The calcaneal facets which articulate with those on the talus show both racial and individual differences. In anatomical texts the anterior and posterior facets are often considered to be separate, with the middle facet defined as being a continuation of the anterior facet. While it is important to define and appreciate these differences in many professions which require accurate diagnosis and treatment, there appears to be no detailed understanding concerning these differences (Williams \& Bannister; Uygur et al.).
The first constitutive features of the subtalar joint begin in the 8th week of gestation, with the the talus and calcaneus being cartilaginous precursors. In the 11th week the cavitational process to form the subtalar joint develops differently in the anterior, middle and posterior regions. The embryology of the subtalar joint and formation of the articular facets on the calcaneus for the talus is extremely important for future joint function (Sharada et al.). Racial differences are also present in developing fetuses, probably being genetically determined rather than resulting from other postnatal factors. Nevetheless, it is unlikely that the high occurrence of the separate type of facet is common in all populations (Jung et al.).

Table IV. The comparison between the our results with those of the other authors as regards with the types of articular facets of the talus.

\begin{tabular}{|c|c|c|c|c|c|c|c|c|c|c|c|}
\hline \multirow[t]{2}{*}{ Authors } & \multirow{2}{*}{$\begin{array}{l}\text { Population } \\
\text { (number of cases) }\end{array}$} & \multicolumn{10}{|c|}{ Type (\%) } \\
\hline & & $\mathbf{A}$ & A1 & A2 & A3 & A4 & B & B1 & B2 & $\mathbf{C}$ & Others \\
\hline Arora (1979) & Indians $(\mathrm{n}=500)$ & 19 & 3 & & & 16 & 79 & 78 & 1 & 2 & \\
\hline Bilodi (2006) & Indians $(n=240)$ & 15 & 5 & & & 10 & 66.6 & 50 & 16.6 & 18.4 & \\
\hline Lee JY (2012) & Korean $(n=76)$ & 39.5 & 9.2 & & & 30.3 & 60.5 & 28.9 & 31.6 & 0 & \\
\hline Cho (2014) & Korean $(n=61)$ & 54.1 & 6.6 & & & 47.5 & 37.7 & 23 & 14.7 & 0 & 8.2 \\
\hline Jung (2015) & Korean $(n=118)$ & 11 & - & - & - & - & 89.0 & 46.6 & 42.4 & 0 & \\
\hline Present study & Turkish $(\mathrm{n}=57)$ & 1.7 & 0 & 1.7 & 0 & 0 & 98.3 & 55.9 & 42.4 & 0 & \\
\hline
\end{tabular}

Table V. The comparison between the our results with those of the other authors as regards with the types of articular facets of the calcaneus.

\begin{tabular}{|c|c|c|c|c|c|c|c|c|c|c|c|}
\hline \multirow[t]{2}{*}{ Authors } & \multirow{2}{*}{$\begin{array}{l}\text { Population } \\
\text { (number of cases) }\end{array}$} & \multicolumn{10}{|c|}{ Type (\%) } \\
\hline & & $\mathbf{A}$ & A1 & A2 & A3 & A4 & B & B1 & B2 & $\mathbf{C}$ & Others \\
\hline & Veddah $(\mathrm{n}=10)$ & 0 & - & - & - & - & 60 & - & - & 40 & \\
\hline Bunning and Barnett & British $(n=194)$ & 67 & - & - & - & - & 33 & - & - & 0 & \\
\hline \multirow[t]{2}{*}{ (1965) } & Indians $(\mathrm{n}=78)$ & 22 & - & - & - & - & 78 & - & - & 0 & \\
\hline & Africans $(n=492)$ & 36 & - & - & - & - & 63 & - & - & 1 & \\
\hline Gupta (1977) & Indians $(\mathrm{n}=401)$ & 31 & 9 & 4 & 13 & 5 & 67 & 28 & 39 & 2 & \\
\hline Padmanabhan (1986) & Indians $(\mathrm{n}=272)$ & 35 & - & - & - & - & 65 & - & - & 0 & \\
\hline $\begin{array}{l}\text { Campos and Pellico } \\
\text { (1989) }\end{array}$ & Spain $(n=176)$ & 46 & 3 & 21 & 16 & 6 & 54 & 29 & 25 & 0 & \\
\hline Ragab (2003) & Americans $(\mathrm{n}=1056)$ & 37 & - & - & - & - & 45.6 & - & - & 0.2 & 17.2 \\
\hline Uygur (2009) & Turkish $(\mathrm{n}=221)$ & 39.4 & 4.1 & 13.1 & 17.2 & 5 & 58.4 & 25.4 & 33 & 2.2 & \\
\hline Mini Mol (2012) & (Mumbai) & 26 & 22 & 2 & 2 & 0 & 74 & 40 & 34 & 0 & \\
\hline Sharada (2012) & Indians $(\mathrm{n}=300)$ & 31.7 & 5.3 & 13.7 & 9.7 & 3 & 67 & 16.6 & 50.4 & 1.3 & \\
\hline Sarvaiya (2012) & (Gujarat) & 30.8 & 5.6 & 10.8 & 9.6 & 4.8 & 68.8 & 42.8 & 26 & 0.4 & \\
\hline Garg (2013) & Indians (Rajasthan) & 25.8 & - & - & - & - & 72.3 & - & - & 1.6 & 0.3 \\
\hline Anjaneyulu (2014) & Indians (North-East) & 36 & 10 & 10 & 11 & 5 & 62 & 43 & 19 & 2 & \\
\hline Chavan (2014) & Indians $(\mathrm{n}=60)$ & 25 & - & - & - & - & 68.3 & - & - & - & 6.7 \\
\hline Jung (2015) & Korean $(n=118)$ & 39 & - & - & - & - & 61 & 32.2 & 28.8 & 0 & \\
\hline Kullar (2015) & Indians $(n=200)$ & 27 & 15 & & 10.5 & 1.5 & 72.5 & 30 & 42.5 & 0.5 & \\
\hline Present study & Turkish $(\mathrm{n}=57)$ & 38.5 & 8.7 & 12.4 & 13.9 & 3.5 & 61.5 & 26.1 & 35.4 & 0 & \\
\hline
\end{tabular}


The number and arrangement of articular facets on the talus and calcaneus have been described by various authors: the observations of the current study are consistent with those previously reported (Tables IV and V). In the current study of Anatolian tali and calcanei the majority of talar articular facets were type B (B1, $55.9 \%$; B2, $42.4 \%$ ) on both left and right sides. Similarly, the majority of calcaneal articular facets were also type B (B1, 26.1\%; B2, $35.4 \%$ ) on both sides, with the remainder being type A (A1, $8.7 \%$; A2, $12.4 \%$; A3, $13.9 \%$; A4, $3.5 \%$ ).

Similar to the current study type B was most commonly observed on tali in Indian (Arora et al., 1979; Bilodi; Chavan et al., 2014) and Korean (Lee et al., 2012; Jung et al.) populations. However, this differs from Cho et.al., who reported type A to be the most common in a Korean population.

In Indians (Bunning \& Barnett; Gupta et al.; Padmanabhan, 1986; Mol et al.; Sharada et al.; Sarvaiya et al.; Garg et al.; Anjaneyulu et al.; Kullar et al., 2015), Koreans (Jung et al.), Africans (Bunning \& Barnett), Veddah (Bunning \& Barnett) and Turks (Uygur et al.) type B was the commonly observed calcanei. The current study observations are similar to those on Indians, Koreans, Africans, Veddah and Turkish populations, but differ from Bunning \& Barnett, Forriol Campos \& Gomez Pellico and Ragab et al., (2003) on British, Spanish and American populations, respectively.
A detailed knowledge of variations in talocalcaneal anatomy, as well as the variable morphology of talocalcaneal coalition, will help radiologists accurately identify and interpret pathology and anatomic variations in the subtalar region (Linklater et al., 2009). The aims of intervention are restoration of the articular facets of the subtalar joint and restoration of talocalcaneal coalition. With the benefit of improvements in technology there have been developments in subtalar implants, flaps and foot protheses. Detailed anatomic information is therefore necessary to enable further development of treatment procedures (Uygur et al.).

The dimensions of the talus and calcaneus determined in the current study are consistent with those reported by others (Tables VI and VII). In current study, measurements of the talus are similar to those of Lee et al. (2012) and Jung et al., on Koreans; however the width and length of the sulcus tali differed from those reported by Koshy et al., (2002) in Indians. Measurements of the calcaneus were similar to Jung et al., on Koreans and Uygur et al., on Turks; however the width of the sulcus calcanei in the current study also differed from Koshy et al., in Indians. Furthermore, the width and length of sulcus calcanei in the current study differed from those reported by Sarvaiya et al., in Indians. These differences may be due to different reference points being used for taking the measurements, as well as racial differences.

Table VI. Comparison between the curent observations and those previously reported regarding measurement of the talus.

\begin{tabular}{|c|c|c|c|c|c|c|}
\hline \multirow[t]{2}{*}{ Authors } & \multirow{2}{*}{$\begin{array}{l}\text { Population } \\
\text { (number of cases) }\end{array}$} & \multicolumn{5}{|c|}{ Parameters (mm) } \\
\hline & & $\begin{array}{l}\text { Anteroposterior } \\
\text { length }\end{array}$ & $\begin{array}{l}\text { Transverse } \\
\text { width }\end{array}$ & $\begin{array}{ll}\text { Width } & \text { of } \\
\text { sulcus tali }\end{array}$ & $\begin{array}{l}\text { Length of sulcus } \\
\text { tali }\end{array}$ & $\begin{array}{l}\text { Depth of } \\
\text { sulcus tali }\end{array}$ \\
\hline Koshy (2002) & Indians $(\mathrm{n}=70)$ & $52.8 \pm 5.8$ & $37.9 \pm 3.5$ & $27.8 \pm 4.4$ & $38.0 \pm 4.1$ & $6.9 \pm 1.05$ \\
\hline Lee UY (2012 ) & Korean $(n=140)$ & $53.92 \pm 3.20$ & $40.48 \pm 2.46$ & - & - & - \\
\hline Jung (2015) & Korean $(n=118)$ & - & - & $4.76 \pm 1.0$ & - & - \\
\hline Present study & Turkish $(\mathrm{n}=57)$ & $51.78 \pm 4.09$ & $39.41 \pm 3.31$ & $5.65 \pm 1.57$ & $21.36 \pm 3.19$ & $5.69 \pm 1.18$ \\
\hline
\end{tabular}

Table VII. Comparison between the curent observations and those previously reported regarding measurement of the calcaneus.

\begin{tabular}{|c|c|c|c|c|c|c|}
\hline Authors & $\begin{array}{l}\text { Population } \\
\text { (number } \\
\text { cases) }\end{array}$ & $\begin{array}{l}\text { Parameters (mm } \\
\text { Anteroposterior } \\
\text { length }\end{array}$ & $\begin{array}{l}\text { Transverse } \\
\text { width }\end{array}$ & $\begin{array}{l}\text { Width of sulcus } \\
\text { calcanei }\end{array}$ & $\begin{array}{l}\text { Length of } \\
\text { sulcus calcanei }\end{array}$ & $\begin{array}{l}\text { Depth of sulcus } \\
\text { calcanei }\end{array}$ \\
\hline Koshy (2002) & Indians $(n=110)$ & $73.6 \pm 5.7$ & $40.8 \pm 4.6$ & $21.1 \pm 2.4$ & $31.9 \pm 3.5$ & $3.4 \pm 0.9$ \\
\hline Uygur (2009) & Turkish $(n=221)$ & $77.7 \pm 5.65$ & $47.5 \pm 4.2$ & $6.15 \pm 2.7$ & $30.4 \pm 3.1$ & $2.55 \pm 0.7$ \\
\hline Sarvaiya (2012) & $\begin{array}{l}\text { Indians (Gujarat) } \\
(\mathrm{n}=250)\end{array}$ & $74.36 \pm 6.6$ & $38.57 \pm 3.12$ & $15.28 \pm 1.94$ & $10.44 \pm 1.66$ & $4.36 \pm 1.0$ \\
\hline Jung (2015) & Korean $(n=118)$ & - & - & $5.16 \pm 1.16$ & - & - \\
\hline Present study & Turkish $(\mathrm{n}=57)$ & $75.88 \pm 6.1$ & $44.88 \pm 4.09$ & $5.98 \pm 1.09$ & $32.13 \pm 2.99$ & $4.21 \pm 0.93$ \\
\hline
\end{tabular}


The accepted treatment options for complex foot deformities are osteotomy and anatomic reduction, together with relaxation of the soft tissues to obtain a normal-sized, painless and functional foot. In such cases knowledge of the underlying pathological and clinical anatomy of the deformed foot should be understood to enable the formulation of a structurally based treatment plan. In many foot diseases, such as talocalcaneal arthritis and coalition, intraarticular fractures, congenital dysmorphology, flatfoot, valgus deformities, the size and shape of the bones, the relationship between the talus and calcaneus and other bones of the foot must be considered before internal and external fixation and other surgical procedures can be undertaken (Uygur et al.). Furthermore, the talus and calcaneus are frequently excavated in archaeological or forensic settings because of their durability. As such they could prove useful in the identification of unknown skeletal remains if their characteristics for biological profiling are known (Lee et al.).

In summary, the most common type of facets on both the talus and calcaneus in an Anatolian population are type B, although a significant number of calcanei had type A. These observations are consistent with many previous reports; however differences exist with some populations. It is concluded that despite the similarities between populations there are sufficient differences that these should be taken into account for orthopaedic, forensic and anthropologic purposes.

BOYAN, N.; OZSAHIN, E.; KIZILKANAT, E.; SOAMES, R. \& OGUZ, O. Mediciones morfométricas y tipos de facetas articulares en el talus y calcáneo de una población Anatolia. Int. J. Morphol., 34(4):1378-1385, 2016.

RESUMEN: Las variaciones anatómicas de ligamentos, articulaciones y morfología ósea son comunes en la región subtalar. La forma de las facetas articulares del talus y calcáneo y su relación mutua son importantes para la función articular y los procedimientos quirúrgicos. En este estudio se realizó una evaluación de la morfología de las facetas articulares del talus y del calcáneo en una población de Anatolia. Se examinaron 49 talus y 57 calcáneos de individuos adultos anatolios de sexo no conocido. Se clasificaron las facetas articulares del talus y el calcáneo de la siguiente manera: Tipo A1, la distancia entre las facetas anterior y media fue inferior a $2 \mathrm{~mm}$; Tipo A2, la distancia entre las facetas anterior y media fue de 2-5 mm; Tipo A3, la distancia entre las facetas anterior y media fue de más de 5 mm; Tipo A4, sólo había una faceta articular; Tipo B1, la separación entre las facetas anterior y media no fue completa; Tipo B2, la separación de las facetas anterior y media estaba presente; Tipo C, no existía separación entre las facetas anterior, media y posterior, es decir, había una faceta articular. Además, se determinó la longitud anteroposterior y el ancho del talus y del calcáneo, junto con el ancho, la longitud y la profundidad del surco talar y del surco del calcáneo. Los talus izquierdo y derecho, respectivamente, mostraron los siguientes tipos de faceta articular: A1, $0 \%, 0 \%$; A2, $0 \%, 3,4 \%$; A3, $0 \%, 0 \%$; A4, $0 \%, 0 \%$; B1, $60 \%, 51,8 \%$; B2, 40 \%, 44,8 \%. Las facetas articulares de los calcáneos izquierdo y derecho, respectivamente, fueron: A1, 10\%, 7,4 \%; A2, 10\%, 14,8 \%; A3, 16,7 \%, 11,1\%; A4, 3,3 $\%, 3,7 \% ; \mathrm{B} 1,30 \%, 22,2 \% ; \mathrm{B} 2,30 \%, 40,8 \%$. La longitud y el ancho de talus izquierdo y derecho fueron 50,5 $\pm 3,81 \mathrm{~mm}$ y $39,5 \pm 2,97 \mathrm{~mm}$, y $53,1 \pm 4,38 \mathrm{~mm}$ y $39,3 \pm 3,66 \mathrm{~mm}$, respectivamente. El ancho, la longitud y la profundidad del surco talar izquierdo y derecho fueron: $5,2 \pm 1,09 \mathrm{~mm}, 21,7 \pm 2,73 \mathrm{~mm}$ y $5,7 \pm 0,84 \mathrm{~mm}$, y $6,1 \pm 2,05 \mathrm{~mm}, 21,1 \pm 3,66 \mathrm{~mm}$ y $5,7 \pm 1,52 \mathrm{~mm}$, respectivamente. Para el calcáneo izquierdo y derecho, la longitud y ancho fueron: $76,1 \pm 5,44 \mathrm{~mm} 44,0 \pm 3,97 \mathrm{~mm}$ y $75,7 \pm 6,76 \mathrm{~mm}$ y $45,9 \pm 4,21 \mathrm{~mm}$, respectivamente. El ancho, longitud y profundidad del surco del calcáneo izquierdo y derecho fueron: $6,4 \pm 1,19 \mathrm{~mm}, 31,9 \pm 2,76 \mathrm{~mm}$ y 4,0 $\pm 0,81 \mathrm{~mm}$, y $5,5 \pm 1,00 \mathrm{~mm}, 32,4 \pm 3,23$ mm y 4,4 $\pm 1,05 \mathrm{~mm}$, respectivamente. Las facetas articulares, tanto en el talus como en el calcáneo en la población de Anatolia estudiada, eran predominantemente de tipo B. Estas observaciones son similares a reportes previos realizados en América, India y África, pero difieren de los realizados en Europa. Un conocimiento de las variaciones de las facetas articulares del talus y del calcáneo proporciona una valiosa hoja de ruta para los cirujanos ortopédicos, así como otros involucrados en la rehabilitación de los pies.

PALABRAS CLAVE: Calcáneo; Faceta; Talus; Subtalar.

\section{REFERENCES}

Anjaneyulu, K.; Philips, C.; Tamang, B. K. \& Kumar, A. Patterns of talar articulating facets in adult human calcanei from NorthEast India and their clinical correlation. Asian J. Med. Sci., 5(4):89-93, 2014.

Arora, A. K.; Gupta, S. C.; Gupta, C. D. \& Jeyasingh, P. Variations in calcanean facets in Indian Tali. Anat. Anz., 146(4):377-80, 1979 .
Bilodi, A. K. 2006. Study of calcaneal articular facets in human tali. Kathmandu Univ. Med. J. (KUMJ), 4(1):75-7, 2006.

Bunning, P. S. \& Barnett, C. H. A comparison of adult and foetal talocalcaneal articulations. J. Anat., 99:71-6, 1965.

Forriol Campos, F. \& Gomez Pellico, L. Talar articular facets (facies articulares talares) in human calcanei. Acta Anat. (Basel), 134(2):124-7, 1989. 
Chavan, S. K.; Satpute, S. T. \& Wabale, R. N. Pattern of talar articular facet of human calcaneum bone. I. O. S. R. J. Dent. Med. Sci., 13(8):16-8, 2014.

Cho, H. J.; Kwak, D. S. \& Kim, I. B. Analysis of movement axes of the ankle and subtalar joints: relationship with the articular surfaces of the talus. Proc. Inst. Mech. Eng. H, 228(10):10538, 2014.

Garg, R.; Dagal, N.; Kumar, S. \& Shekhawat, S. Study of patterns of talar articular facets of human calcanei and their clinical implications in population of Rajasthan. Indian J. Basic Appl. Med. Res., 2(7):643-50, 2013.

Gupta, S. C.; Gupta, C. D. \& Arora, A. K. Pattern of talar articular facets in Indian calcanei. J. Anat., 124(Pt. 3):651-5, 1977.

Jung, M. H.; Choi, B. Y.; Lee, J. Y.; Han, C. S.; Lee, J. S.; Yang, Y. C. \& Cho, B. P. Types of subtalar joint facets. Surg. Radiol. Anat., 37(6):629-38, 2015.

Koshy, S.; Vettivel, S. \& Selvaraj, K. G. Estimation of length of calcaneum and talus from their bony markers. Forensic Sci. Int., 129(3):200-4, 2002.

Kullar, J. S.; Arora, A. K.; Kapoor, N. S.; Randhawa, G. K. \& Kullar, K. K. Morphology of talar articular facets of calcaneus and its clinical implications. Kashmir J. Med. Sci., 1(1):10-4, 2015.

Lee, J. Y.; Jung, M. H.; Lee, J. S.; Choi, B. Y. \& Cho, B. P. Types of calcaneal articular facets of the talus in Korean. Korean J. Phys. Anthropol., 25(4):185-92, 2012.

Lee, U. Y.; Han, S. H.; Park, D. K.; Kim, Y. S.; Kim, D. I.; Chung, I. H. \& Chun, M. H. Sex determination from the talus of Koreans by discriminant function analysis. J. Forensic Sci., 57(1):166-71, 2012.

Linklater, J.; Hayter, C. L.; Vu, D. \& Tse, K. Anatomy of the subtalar joint and imaging of talo-calcaneal coalition. Skeletal Radiol., $38(5): 437-49,2009$

Mol, P. M.; Silotry, N., Kumari, N. H. Morphological study on patterns of talar articular facets of human calcanei. Int. J. Med. Clin. Res., 3(3):136-9, 2012

Öznur, A.; Akça, M. K.; Koyuncu, B. \& Turhan, E. Talus kırıkları: Deg `erlendirme ve tedavi. TOTBI 'D Dergisi, 12(2):159-67, 2013.

Padmanabhan, R. The talar facets of the calcaneus--an anatomical note. Anat. Anz., 161(5):389-92, 1986.

Ragab, A. A.; Stewart, S. L. \& Cooperman, D. R. Implications of subtalar joint anatomic variation in calcaneal lengthening osteotomy. J. Pediatr. Orthop., 23(1):79-83, 2003.
Sarvaiya, B. J.; Patel, S. V.; Single, G. \& Master, D. C. The types of talar articular facets and morphometric measurements of the human calcaneum bone of Gujarat Region. Nat. J. Integr. Res. Med., 3(3):34-8, 2012.

Shahabpour, M.; Devillé, A.; Van Roy, P.; Vaes, P.; De Mey, J. \& De Maeseneer, M. Magnetic resonance imaging of anatomical variants of the subtalar joint. Surg. Radiol. Anat., 33(7):623$30,2011$.

Sharada, R.; Sneha, K.; Gupta, C.; Pai, S. R. \& Rairam, G. B. Nonmetrical study of the pattern of talar articular facets in south Indian dry calcanei. Surg. Radiol. Anat., 34(6):487-91, 2012.

Williams, P. L. \& Bannister, L. H. Gray's Anatomy: The Anatomical Basis of Medicine and Surgery. 38th ed. New York, Churchill Livingstone, 1995. pp.713-6.

Uygur, M.; Atamaz, F.; Celik, S. \& Pinar, Y. The types of talar articular facets and morphometric measurements of the human calcaneus bone on Turkish race. Arch. Orthop. Trauma Surg., 129(7):909-14, 2009.

Correspondence to:

Prof. Dr. Ozkan OGUZ Cukurova

University Faculty of Medicine

Department of Anatomy 01330

Balcali - Adana

TURKEY

Email : ozoguz@cu.edu.tr

Received: 12-05-2016

Accepted: 23-08-2016 